OPEN ACCESS

Edited by:

Joji Muramoto,

University of California, Santa Cruz,

United States

Reviewed by:

Christopher Bacon,

Santa Clara University, United States

llias Travlos,

Agricultural University of

Athens, Greece

*Correspondence:

Mélanie Surchat

msurchat@ethz.ch

Specialty section

This article was submitted to Agroecology and Ecosystem Services,

a section of the journal

Frontiers in Sustainable Food Systems

Received: 12 May 2021

Accepted: 06 July 2021

Published: 04 August 2021

Citation:

Surchat $M$, Wezel A, Tolon V, Breland TA, Couraud $P$ and Vian J-F (2021) Soil and Pest Management in

French Polynesian Farming Systems

and Drivers and Barriers for

Implementation of Practices Based on

Agroecological Principles.

Front. Sustain. Food Syst. 5:708647.

doi: 10.3389/fsufs.2021.708647

\section{Soil and Pest Management in French Polynesian Farming Systems and Drivers and Barriers for Implementation of Practices Based on Agroecological Principles}

\author{
Mélanie Surchat ${ }^{1 *}$, Alexander Wezel ${ }^{1}$, Vincent Tolon ${ }^{1}$, Tor Arvid Breland ${ }^{2}$, \\ Philippe Couraud ${ }^{3}$ and Jean-François Vian ${ }^{1}$ \\ ${ }^{1}$ Isara, AgroSchool for Life, Agroecology and Environment Research Unit, Lyon, France, ${ }^{2}$ Department of Plant Sciences, \\ Faculty of Biosciences, Norwegian University of Life Sciences, Ås, Norway, ${ }^{3} D A G$, Direction de l'Agriculture, Pape'ete, \\ French Polynesia
}

In the context of climate change, French Polynesia is committed to increasing qualitatively and quantitatively local food production. In this regard, agroecology is perceived as a sustainable pathway to improve farming practices. This article proposes first a theoretical framework to analyze the proximity of farmers' management to agroecological principles. Second, it describes the current use of agroecological pest and soil management practices by French Polynesian farmers. And third, it explains which agronomic and socio-economic factors drive the implementation of agroecological practices. For this, qualitative interviews were conducted with 32 farmers on three islands, and statistical analyses were carried for correlation between the use of practices and socio-economic variables. Results show that French Polynesian farmers implement different soil and pest management practices that are in line with agroecological principles. Farmers scored better in terms of pest management with high plant diversity, implementation of crop rotations, and mechanical weed management. There is a significant influence of the "cropping system" and the "production system" (organic, integrated, and conventional) on the use of practices as well as proximity to agroecological principles. Identified pathways for an agroecological transition are implementing farmer to farmer knowledge exchange, farmer networks, and farm demonstrations as well as training of extension services staff.

Keywords: transition pathways, agroecological practices, agroecology, innovation tracking, organic agriculture, Tahiti

\section{INTRODUCTION}

French Polynesia faces major challenges for future development because of expected climate change impacts with rising sea levels, coral bleaching that threatens fisheries and natural barriers against heavy storms, and loss of endemic species linked to the loss of insular habitats (Bellard et al., 2013; Communauté du Pacifique Sud, 2017). In addition, its geographical remoteness-with 116 islands isolated in the middle of the Pacific Ocean-leads to challenging trade relations with other 
countries. In the context of peak oil, food security could be threatened, as French Polynesian inhabitants are heavily dependent on food imports. Furthermore, there are general constraints to be addressed in terms of local agricultural development such as the lack of arable land linked to challenging topography on the volcanic islands, poor soils on the atolls, issues of land ownership, and lack of structuring of the food sector, with an important flow of agricultural products sold on informal markets, e.g., in the streets (Institut d'émission d'outre-mer, 2017).

Agricultural land covers $9 \%$ of the terrestrial surface of the country, representing the equivalent of 39,000 ha; $74 \%$ of this land is covered by coconut plantations, $18 \%$ by pastures, and $8 \%$ by crops (Service du Développement Rural, 2012). In terms of tonnage, copra represents $27 \%$ of the total agricultural production, vegetables $17 \%$, fruit $16 \%$, and traditional crops $^{1} 3 \%$ (Institut d'émission d'outre-mer, 2017). Agriculture in French Polynesia is based on a poorly structured family farming model, consisting of small polyculture farms, with $48 \%$ of the holdings producing on $<0.5$ hectares (Service du Développement Rural, 2012). Overall, farmers have little education and $90 \%$ of them have not received agricultural training (Service du Développement Rural, 2012).

In $2015,41 \%$ of the vegetable and $67 \%$ of the fruit consumption was produced locally, meaning that two out of three vegetables are imported (Institut d'émission d'outre-mer, 2017). The prices are regulated by the administrative law $n^{\circ} 2004$ 192 from the 27.02.2004 (LEGIFRANCE, 2004), relating to the status of autonomy of French Polynesia toward France. This means that the local government controls the market prices and margins on food products (Institut d'émission d'outre-mer, 2017). Recently, when acknowledging the new threats on food security, it became a priority for the government to increase the quantity of food produced locally (Ministère de l'Economie Rurale, 2011). This is reflected in the present research, which focuses on fruit, vegetable, and staple crops as they represent most of the agricultural production, and as they can provide important elements to improve food security.

Reduction of synthetic fertilizers and pesticides is another target set by the Direction of Agriculture, which has joined a Pacific program that seeks a transition toward integrated coastal management that would preserve the natural marine and terrestrial biodiversity (Communauté du Pacifique Sud, 2017). Indeed, a couple of studies have highlighted pesticide contamination of marine organisms at various trophic levels (Roche et al., 2011). Salvat et al. (2012) showed that chemicals have contaminated even the most remote areas, such as atolls from the Tuamotu Archipelago. Therefore, decreasing pesticide use has become vital for the environment, but also human health, as concerns have been growing in the local population about their potential negative health impacts (Carrère, 2017). Inappropriate application of synthetic fertilizers (especially $\mathrm{N}$ and $\mathrm{P}$ ) can also be

\footnotetext{
${ }^{1}$ The main traditional crops (Institut d'émission d'outre-mer, 2017): uru (Artocarpus altilis), yam (genus Dioscorea), tarua (Xanthosoma sagittifolium), sweet potato (Ipomoea batatas), fei banana (genus Musa), taro (Colocasia esculenta).
}

problematic by polluting water (e.g., eutrophication), decreasing soil organic matter content, and increasing soil acidification (Kopittke et al., 2019). The intensified cropping systems, often associated with the use of synthetic fertilizers, may eventually amplify the soil erosion (Kopittke et al., 2019), which is occurring on steep slopes during the heavy tropical rains that are common in French Polynesia (Seguin, 2015). For this reason, reducing soil erosion is another major target for French Polynesian agriculture (Ministère de l'Economie Rurale, 2011).

Agroecology, understood as "the ecology of food systems" (Francis et al., 2003) and "a systemic, transdisciplinary, participatory, and action-oriented approach" (Méndez et al., 2015) is-by systems thinking (Olson and Francis, 1995; Gliessman, 2015) and ecologically founded principles for selection of practices (Altieri and Nicholls, 1999; Gliessman, 2015) - a strategy for more sustainable management of the agroecosystems including improved quality and quantity of the food production, decreased use of synthetic pesticides and fertilizers, and mitigation of soil erosion (McIntyre et al., 2009; Nicholls et al., 2017). Since recently, French Polynesia is involved in an international program (the 11th European Fund for Development-FED in French) that aims to promote an agroecological transition and the development of organic farming (Service Public, 2018a). This funding scheme is the only type of payment that French Polynesian farmers can seek from the European Commission, as they are not subject to payments under the EU Common Agricultural Policy. Four territories that share similar challenges are involved in this FED program: New Caledonia, French Polynesia, Wallis and Futuna, and the Pitcairn Islands. One of the objectives of this program is to develop so-called "agroecological practices" in these countries, which may be defined as practices best utilizing ecological processes and ecosystem services for food production (Wezel et al., 2014).

It is important to keep in mind, though, that by definition of agroecology as a whole-system approach to managing integrated social, economic, and ecological agricultural systems, a single agronomic practice can hardly be considered agroecological per se. It is the criteria for the selection of practices and their systemic integration into the site- and time-specific contexts through multi-perspective, multi-scale, ecologically sound systems thinking that makes up agroecology. Further, the question of compliance with agroecological principles is not a simple binary one, as a transition toward ecologically sounder agroecosystems may be considered as more or less consecutive stages of efficiency increase, input substitution, and redesign of cropping and even farming and food systems (Gliessman, 2015; Wezel et al., 2020). The need for agroecological thinking increases as complexity increases.

The present work took place in the frame of the 11th FED. As there is no recent data on farmers' practices in French Polynesia, a transition first requires a characterization of a baseline of currently common practices. Both "classical" and innovative farmers developing improved practices need to be interviewed to identify the main sociological, cultural, economic, and technical barriers and drivers for implementing cropping practices better aligned with agroecological principles (Magrini and Triboulet, 
2012; Meynard, 2012). Targeting pioneer farmers by following "innovation tracking" (Meynard, 2012) is important. This allows us to view farmers as change agents who can facilitate the adoption of alternative practices by other farmers (Padel, 2001; Rogers, 2003; Salembier et al., 2016; Casagrande et al., 2017).

This study has four objectives of which three are linked to research questions (RQs):

1. To propose a theoretical framework for describing the proximity of a farmer's pest and soil management practices to agroecological principles pertaining primarily to the physical and biological (ecological) system dimension (PestScore, SoilScore).

2. To investigate to which extent soil and pest management practices that are known to preserve soil fertility and reduce pesticide and synthetic fertilizer use, are being applied by selected farmers in different cropping systems (vegetables, fruits, pineapple, traditional crops) in French Polynesia.

RQ1: To what extent are soil and pest management practices aligned with the use of agroecological principles?

3. To understand which socioeconomic and agronomic factors are significantly correlated with the farmer pest and soil management practices.

RQ2: Which socioeconomic and agronomic factors explain the farmers' soil and pest management proximity to agroecological principles?

4. To identify the main barriers and drivers for a broader implementation of desirable practices.

RQ3: What are the barriers and drivers for the further implementation of agroecological soil and pest management practices?

The study was carried out on the Tahiti, Moorea, and Raiatea islands by interviewing a selection of classical and more innovative farmers producing fruits, vegetables, and staple crops that are important to decrease the dependency on food imports in French Polynesia. The interviews were carried out following a holistic approach including the economical, technical and sociocultural factors and their interactions.

\section{MATERIALS AND METHODS}

\section{Study Area (Pedoclimatic Conditions and Markets) and Crops Studied}

The islands of Tahiti and Moorea, located in the Windward Islands, and Raiatea, located in the Leeward Islands, are characterized by coastal flatlands and central mountainous areas. Due to the volcanic nature of the islands, the soils suitable for agricultural production are those resulting from the accumulation of erosion detritus (Couraud, 1985). These soils are developed on the colluvial or alluvial deposits of the lower parts of the islands, on the littoral plains, the lower slopes, and in the valleys. These are young soils (low evolutionary status) showing hydromorphic characteristics. The farms located on the flat coastal plains, on the opposite, show higher sand content in the soil and have therefore important drainage capacity (Couraud, 1985). The 32 farms in the sample were located on these two major types of soils (resulting from detritus accumulation or on the coastal plain). However, as most of the farmers have not conducted any soil tests, a further characterization of the soil types cannot be presented for the sample.

The meteorological characteristics of the three islands can be comparable with a rainy season (November to April) and a dryer season (May to October) that result mostly from the northeastern or eastern trade winds (Couraud, 1985). Precipitation patterns vary on each island mostly due to location (eastern coast is more humid), topography and altitude (lower flat lands are dryer). These patterns can be explained by the orographic mechanisms at the origin of rainfall (Wotling et al., 2000). Depending of the farm location (leeward or windward side of the island), the annual rainfall varies significantly between 1,500 and 3,500 mm approximately [Ferry, 1988 cited in Wotling et al. (2000)]. However, as detailed data on rain patterns for the specific locations of the farms does not exist, we cannot describe how these differences affect the observed farming practices.

Concerning the farmer connection to markets, the conditions on the three islands are comparable. Tahiti, as the capital of French Polynesia, is the most connected island to external markets. Moorea also benefits from a good connectivity to markets and multiple daily boat connections with Tahiti (only $27 \mathrm{~km}$ away from Tahiti). The situation of Raiatea is slightly different as it is located $234 \mathrm{~km}$ away from Tahiti. As Raiatea is the main island within the Leeward Islands, it benefits from numerous boat connections with Tahiti, but the market accessibility and access to importations are affected by the distance.

Our study focused on the crops that represent the biggest part of the agricultural production in French Polynesia: fruits, vegetables, and staple crops. Staple crops are defined in French Polynesia as banana, fei banana, igname, cassava, sweet potato, taro, tarua, and uru (Institut d'émission d'outre-mer, 2017). Cattle and other ruminant productions are not suited to the topography of the volcanic islands (steep slopes) and the general shortage of agricultural land does not allow farmers to possess vast spaces for cattle. Therefore, livestock production systems were not included in the survey. Crops are produced mostly in two archipelagos in French Polynesia, the Windward Islands (annual total production in 2015 of $3,105 \mathrm{Mg}$ of vegetables, $4,263 \mathrm{Mg}$ of fruit, and $357 \mathrm{Mg}$ of traditional crops) and the Leeward islands (261 Mg of vegetables, 1,610 Mg of fruit, $192 \mathrm{Mg}$ of traditional crops) (Service du Développement Rural, 2016). This is the reason for choosing to analyze farmers' practices and systems on the islands of Tahiti, Moorea, and Raiatea.

\section{Farmers Interviews}

We interviewed 32 farmers selected on the basis of their conventional or innovative pest and soil practices and their type of cropping systems (staple crop, fruit, vegetable, mixed, and pineapple). This judgment was conducted a priori by representatives from the local extension services from the Chamber of Agriculture (CAPL) and the Direction of Agriculture (DAG) that work closely with the farmers. The farmers recruited for this study participated on a voluntary basis. Seventeen farms were located on Tahiti, 12 on Raiatea, and three on Moorea. 
The interviewer spent $\sim 2 \mathrm{~h}$ with each farmer on his or her farm to describe farming management. As some of the farmers interviewed did not speak French fluently, the possibility to show their crops and machinery facilitated the understanding for the interviewer. The interviewer carried out semi-directed interviews following the framework developed by Capillon and Manichon (1991). This framework provides a holistic view of the farming system by considering the farmer's background and objectives, farm inputs and outputs, and main social, cultural, economic, biological-physical, and technical factors. After having obtained an overview of the context, the focus was set on the crop production to understand the farmer's choice of crops and cultivars and spatial and temporal organization of cash crops, cover crops, and fallows. Finally, more specific questions concerning pest and soil management were asked for each crop (e.g., organic amendments, fertilization strategies, and use of synthetic or natural pesticides).

\section{Characterization of Soil and Pest Management Practices}

To determine the proximity of farmers' practices to what is considered agroecologically sounder soil and pest management as viewed mainly in a physical and biological (ecological) perspective (objective 1), we conducted a literature review. Our attention was drawn to the FAO "10 elements of agroecology" (FAO, 2018) and their recent operational performance tool called TAPE-Tool for Agroecology Performance Evaluation (FAO, 2019). We see TAPE as a robust tool that can be used to describe production systems in a comprehensive way (Mottet et al., 2020), touching upon "environmental, social \& cultural, economic, health \& nutrition, and governance dimensions of sustainability to support agroecological transitions at different scales, in different locations, through different timeframes and to support context-specific policy-making on agroecology" (FAO, 2019 , p. 6). This holistic view on the food system is consistent with the wide definition of agroecology outlined above in the Introduction section but for obvious, practical reasons, it does not delve into detail in the biological-physical dimension of the system, e.g., about the actual farming practices, which was the scope of the present characterization.

For a similar reason, we did not use the 10 elements of agroecology, but preferred the six principles defined by Altieri and Nicholls (1999) to design resilient farming systems, as these are more descriptive of the physical and biological dimension of agricultural systems. These six principles are also closer to the first seven principles as defined in HLPE (2019) and Wezel et al. (2020), which are referring to the physical and biological dimension of the agroecosystem at the farm level. Considering the tropical farming characteristics in French Polynesia, we found the six principles defined by Altieri and Nicholls (1999, p. 6984) relevant to guide our analysis of the use of practices based on ecological principles ${ }^{2}$ :

\footnotetext{
${ }^{2}$ The common use of the term "agroecological practices" may be perceived as reductionist, as an agroecological approach is holistic and will always place a strong emphasis on the functioning of a practice within the context of the whole farming system in its local environment. However, for language simplification, we will refer
}

"(1) Enhance recycling of biomass, optimize matter decomposition and nutrient cycling over time, (2) strengthen the immune system, enhance functional biodiversity by creating appropriate habitats, (3) provide favorable soil conditions for plant growth, manage organic matter by enhancing soil biological activity, (4) enhance beneficial biological interactions and synergies to promote key ecological services, (5) diversify species and genetic resources over time and space at field and landscape level, (6) minimize losses of energy, water, nutrients, and genetic resources by enhancing conservation and regeneration."

Then, we translated these six principles into 11 management practices (MP) that stood out as important to enhance the soil fertility and reduce soil erosion (MP1-MP6, Table 1), and to reduce or suppress pesticide use (MP7-MP11, Table 1) (Altieri and Nicholls, 1999; Wezel et al., 2014; Nicholls et al., 2017).

To answer RQ1, we characterized the overall proximity of each farmer to an "agroecological" soil and pest management. A score of maximum 10 points was attributed to each MP, and each MP could achieve the following grades: (a) close to agroecological principles (10 points), (b) medium proximity to agroecological principles (five points), and (c) far from agroecological principles (zero points). For example, if a farmer manages crop fertilization (MP2) only by using synthetic fertilizers, the farm obtained zero points. If the farmer applies a mix of synthetic and organic fertilizers, the farm obtained five points. To achieve 10 points, crop fertilization had to be solely based on organic resources. Table 2 describes which score corresponds to which degree of implementation of the MP.

Attributing a score to each MP provides a global proxy to a best possible management of soil and pests inside each cropping system. In this investigation, the global score is the sum of the scores attributed to each MP divided by the maximum points achievable for each cropping system. Obviously, some management practices such as "crop rotations" (MP9) cannot be implemented in a fruit orchard based on perennial crops. Therefore, it was necessary to adapt the calculation of the score to include only practices relevant to each cropping system. The global score obtained were divided in sub-scores corresponding specifically to soil (sum of the grades of MP1-MP6) and pest management (sum of the grade of MP7-MP11), respectively, divided by the maximum points achievable in the cropping system considered. The following formulae were applied to calculate the scores:

\footnotetext{
ScoreTot $=$ Sum of the scores of each MP / Maximum points achievable

ScoreSoil $=$ Sum of the scores of MP1 to $6 /$ Maximum points achievable

ScorePest $=$ Sum of the scorres of MP7 to $11 /$ Maximum points achievable
}

Nine parameters (A-I) expected to influence the way farmers manage their production, were recorded on each farm (Table 3). We recorded farmer age (A), farm surface area (B), farm location

to "agroecological practices" as management practices in line with agroecological principles adapted to the given context. 
TABLE 1 | Characterization of the 11 management practices (MP) used by farmers and their benefits.

\begin{abstract}
MP1 On-farm organic matter recycling for soil fertility management: Production of organic matter coming from the farm (crop residues, household compost) or nearby (mainly chicken compost) used as soil amendments. They allow to improve the overall soil quality and thus reduce soil erosion and enhance soil biological activity (Cesarano et al., 2017).

MP2 Crop fertilization: Quantity and frequency of use of fertilizers, organic or/and synthetic. Organic fertilizers like natural fertilizer produced locally from fish and algae residues allow to enhance plant health and decrease the dependency on external inputs. Synthetic fertilizers can increase the risk of ground and surface water contamination (Kopittke et al., 2019).

MP3 Cover-crops: Cover-crops improve soil fertility through biomass accumulation, they stimulate soil biological activities, reduce soil erosion and reduce pest populations (Daryanto et al., 2018).

MP4 Mulching: Utilization of crop residues and/or utilization of landscape elements as a mulch (mowing of grass strips, hedgerows...). Mulching techniques help to prevent soil erosion and also enhance nutrient recycling (Prosdocimi et al., 2016; Agegnehu and Amede, 2017).

MP5 Soil erosion mitigation: Integration of semi-natural landscape elements (vegetation strips and hedges in fields and at field borders) protects from heavy winds and decreases soil wind erosion. Planting the crops following key-lines can also decrease risks of soil water erosion (Wezel et al., 2014).

MP6 Reduced tillage: Reduced tillage with no soil inversion allows to decrease the risks of wind and water erosion and increase soil biota activity and soil organic matter content (Kladivko, 2001).

MP7 Weed management: Mechanical or manual weed management allows to reduce or suppress the use of synthetic herbicides that eventually may pollute surface and ground-waters (Chikowo et al., 2009).

MP8 Plant diversity at farm scale: Plant and crop diversity in space promotes key ecosystem services (pest regulation, nutrient cycling) for agroecosystem function (Altieri and Nicholls, 1999).

MP9 Crop rotation: Crop rotation allows to reduce weed and pest infestations and thus reduce the use of pesticides (Wezel et al., 2014).

MP10 Cultivar choice: Adapted crops and resistant cultivars to biotic and abiotic stresses allows to increase/stabilize yields, and increase resilience to pest attacks (Wezel et al., 2014).

MP11 Biological pest control: Introduction of natural enemies, utilization of pheromones, trap crops, intercrops and utilization of biological pesticides (neem oil, black soap, Bt...) reduce the use of pesticides (Wezel et al., 2014).
\end{abstract}

(C), and farmer's education (D) for a basic description of the samples. We distinguished between five cropping systems (E): vegetables, pineapple, staple crops, fruit, and "mixed system." "Mixed system" was used for more diversified farms where no dominant cropping system could be identified. "Pineapple" was isolated from the "fruit," as pineapple production is mostly grown as a monoculture which is not the case for other fruit species.

The market distribution (F) was considered as "standard" when the farm was selling to multiple distribution channels (big gross retailers, informal stalls on the road, markets, contracts with private people) as that is the norm in French Polynesia. Market distribution was considered as "innovative" when farmers have developed other channels like vegetable boxes delivered every week or when they have developed on-farm food processing to increase farm income.

The presence of external income $(\mathrm{G})$-income from the farmer's partner, pension money, or income from fishing activities-was monitored as it can positively influence the adoption of innovative practices by reducing the economic risk caused by a possible failure. For a similar reason, financial support $(\mathrm{H})$ was ticked for farmers that benefit from a financial support from the European Commission or the French Polynesian State via two main schemes: "Best program" (voluntary scheme for Biodiversity and Ecosystem Services in Territories of European overseas) or "ICRA programs" (in French "Insertion par la Création ou la Reprise d’Activité"). The Best program is financially supported by the European Commission that supports the conservation of biodiversity and the sustainable use of ecosystem services in the outermost regions recognized for their exceptionally rich biodiversity. The ICRA program is a state supported scheme that aims to decrease the unemployment rate in French Polynesia, by creating job opportunities for farm workers, that are paid by the state.
Three production systems (I) were distinguished: organic, integrated and conventional management. Farms were considered as organic when they achieved the organic label or the Participatory Guarantee Scheme (PGS) for organic. Farms were considered as integrated if farmers were engaged in a strategy of inputs reduction in order to improve the sustainability of their farm (without any certificationself declared). All the other farmer types were classified as conventional.

To answer RQ2, we conducted a statistical multivariate analysis to see if these nine factors are significantly correlated with the farmers' SoilScore and PestScore. Finally, as the farmer sample is reduced and the number of each cropping system is too weak to generalize, we answer to RQ3 in the discussion part, by extracting the knowledge gained during the in-depth interviews with the farmers and local agricultural extension services.

\section{Data Analysis}

In our study, we analyzed the effects of the two major agronomic systems descriptors that would directly influence soil and pest management (see Table 5: cropping system, production system) and considered the seven other socio-agro-economic variables as complementary "descriptive variables" (farmer age, farm surface area, location, farmer education, market distribution, external income, and financial support).

Due to our reduced sample size and the strong links both within responses and explanatory variables, we opted for a descriptive analysis of observed patterns. First, we explored one by one the effect of the selected agronomic factors on the bivariate "ScoreSoil" - "ScorePests" response. Then, we described links between the two agronomic factors (production system and cropping system) with socioeconomic variables to improve 
TABLE 2 | Scores (based on the MP - Table 1) attributed to the different management practices implemented by farmers.

\begin{tabular}{|c|c|c|}
\hline \multirow[t]{14}{*}{ Soil management } & \multirow{4}{*}{$\begin{array}{l}\text { 1) On-farm organic matter } \\
\text { recycling for soil fertility } \\
\text { management } \\
\text { 2) Crop fertilization }\end{array}$} & $0=$ no use of organic amendments \\
\hline & & $5=$ not frequently used, depending on the availability of the resources \\
\hline & & $10=$ frequent use (at the beginning of every new cycle of a crop rotation) \\
\hline & & $0=$ mineral fertilizers only \\
\hline & \multirow{2}{*}{ 2) Crop fertilization } & $5=$ mix of mineral and organic fertilizers \\
\hline & & $10=$ organic fertilizers (fish and algae by-products; feather meal, commercial organic fertilizers) \\
\hline & 3) Cover crops & $0=$ no fallow period and no cover-cropping \\
\hline & \multirow[t]{3}{*}{ 4) Mulching } & $0=$ crop residues burnt, no mulching \\
\hline & & $5=$ punctual use of mulching (with crop residues or material from natural elements around fields) \\
\hline & & $10=$ systematic restitution of crop residues as a mulch and/or use of natural elements for mulching \\
\hline & \multirow[t]{2}{*}{ 5) Soil erosion mitigation } & $0=$ no implementation of ecological infrastructures or physical barriers \\
\hline & & $\begin{array}{l}5=\text { implementation of } 1 \text { or } 2 \text { management practices to reduce soil erosion (wind barriers, grass } \\
\text { strips...) }\end{array}$ \\
\hline & \multirow{2}{*}{ 6) Reduced tillage } & $5=$ shallow tillage, mechanized \\
\hline & & $10=$ no tillage or superficial hand tillage for plantation \\
\hline \multirow[t]{9}{*}{ Weed and pest management } & \multirow[t]{3}{*}{ 7) Weed management } & $0=$ chemical weed management \\
\hline & & $5=$ mix of mechanical (or physical by applying plastic covers) and chemical weed management \\
\hline & & $10=$ mechanical and/or hand weeding or mulching with organic residues \\
\hline & \multirow[t]{3}{*}{ 8) Plant diversity } & $0=$ rare presence of landscape elements and low crop diversity ( 1 or 2 species) \\
\hline & & $5=$ disseminated landscape elements and more than 3 crop families \\
\hline & & $10=$ numerous landscape elements and diversified system with a mix of crops (fruits, vegetables...) \\
\hline & \multirow[t]{3}{*}{ 9) Crop rotation } & $0=$ monoculture \\
\hline & & $5=<4$ crops in the crop rotation \\
\hline & & $10=$ complex crop rotation with alternation of species botanical families \\
\hline
\end{tabular}

interpretations. We finally, provided an overall interpretation according to patterns observed amongst farmers' scores and explanatory variables.

To evaluate graphically the potential influence of the two factors on the soil and pests scores, we plotted the "ScoreSoil" (x) with the "ScorePests" (y) and projected every factor modality according to their $\mathrm{x}$ and $\mathrm{y}$ mean value (one plot per factor with as many means as there are possible modalities of the factor). For example, the "production system" factor resulted in a plot of "ScoreSoil" ( $\mathrm{x}$ ) with "ScorePests" (y) including the three modalities (conventional, integrated, and organic) located on their mean $\mathrm{x}$ and $\mathrm{y}$ value. Positions of modalities regarding $\mathrm{x}$ and $\mathrm{y}$ axes can help to determine if the effect occurred on both variables (modalities distributed on a diagonal), on "ScoreSoil" only (horizontal repartition of modalities), or "ScorePests" only (vertical repartition). To complete these graphical observations, we tested the link of each factor with the bivariate ScorePest/ScoreSoil with a Monte Carlo permutation test (99,999 permutations) applied on a discriminant analysis with functions of the package ADE4 package (Dray and Dufour, 2007). The "ScoreSoil" and "ScorePests" were used as quantitative variables and factors were used one by one as the group indicator. We used in addition a Chi-square Monte Carlo permutation procedure (Hope, 1968) to test the links between the two agronomic drivers of the pest/soil score and socio-economic factors (99,999 permutations). We applied a Bonferroni correction for multiple testing by dividing the classical $5 \%$ signification level by the number of tests to detect first-order effects.

\section{RESULTS}

\section{Management Practice Scores}

The 32 farmers were producing on a median farm surface of 3 ha. Sixty percent of the farmers were between 40 and 60 years old, $15 \%$ of them were more than 60 years old and $25 \%<40$ 
TABLE 3 | Characteristics of the 32 farms analyzed in French Polynesia.

\begin{tabular}{|c|c|c|c|c|c|c|c|c|c|}
\hline Farm & Age & Surface & Location & Education & Cropping system & Market distribution & External income & Financial support & Production system \\
\hline F1 & $40-60$ & 4 ha & Tahiti & Higher & Vegetables & Standard & Yes & Yes & Organic \\
\hline F2 & $40-60$ & 29 ha & Tahiti & Higher & Vegetables & Standard & No & Yes & Conv. \\
\hline F3 & $<40$ & 5 ha & Tahiti & Higher & Pineapple & Standard & No & Yes & Integrated \\
\hline F4 & $>40$ & 6 ha & Tahiti & Lower & Mixed system & Innovative & No & Yes & Organic \\
\hline F5 & $>60$ & 0.3 ha & Tahiti & Lower & Mixed system & Standard & No & Yes & Conv. \\
\hline F6 & $40-60$ & 6 ha & Tahiti & Lower & Vegetables & Standard & No & Yes & Conv. \\
\hline F7 & $>60$ & 6 ha & Tahiti & Lower & Staple crops & Standard & No & No & Conv. \\
\hline F8 & $<40$ & 7 ha & Tahiti & Lower & Vegetables & Standard & No & Yes & Conv. \\
\hline F9 & $<40$ & 2 ha & Tahiti & Higher & Vegetables & Innovative & Yes & Yes & Organic \\
\hline F10 & $40-60$ & 5 ha & Moorea & Lower & Pineapple & Standard & No & Yes & Conv. \\
\hline F11 & $40-60$ & 5 ha & Moorea & Lower & Mixed system & Standard & No & No & Conv. \\
\hline F12 & 40-60 & 35 ha & Tahiti & Lower & Fruit & Innovative & Yes & Yes & Integrated \\
\hline F13 & $40-60$ & 3 ha & Raiatea & Higher & Mixed system & Innovative & Yes & Yes & Organic \\
\hline F14 & $40-60$ & 5 ha & Raiatea & Lower & Fruit & Standard & No & Yes & Conv. \\
\hline F15 & $40-60$ & 4 ha & Raiatea & Lower & Staple crops & Innovative & Yes & Yes & Organic \\
\hline F16 & $<40$ & 3 ha & Raiatea & Lower & Mixed system & Standard & No & Yes & Integrated \\
\hline F17 & $<40$ & 1 ha & Raiatea & Lower & Staple crops & Standard & No & No & Organic \\
\hline F18 & 40-60 & 4 ha & Raiatea & Lower & Fruit & Standard & No & Yes & Conv. \\
\hline F19 & $<40$ & 2 ha & Tahiti & Higher & Vegetables & Standard & No & Yes & Organic \\
\hline F20 & $>60$ & 1 ha & Tahiti & Lower & Mixed system & Standard & Yes & Yes & Conv. \\
\hline F21 & $40-60$ & 5 ha & Tahiti & Lower & Staple crops & Standard & No & No & Conv. \\
\hline F22 & $40-60$ & 2 ha & Tahiti & Lower & Vegetables & Standard & No & No & Integrated \\
\hline F23 & $40-60$ & 2 ha & Tahiti & Lower & Vegetable & Standard & Yes & Yes & Integrated \\
\hline F24 & $40-60$ & 3 ha & Tahiti & Higher & Fruit & Innovative & No & No & Organic \\
\hline F25 & 40-60 & 1 ha & Moorea & Lower & Vegetables & Standard & No & Yes & Conv. \\
\hline F26 & 40-60 & 3 ha & Tahiti & Lower & Mixed system & Standard & No & No & Conv. \\
\hline F27 & $<40$ & 3 ha & Raiatea & Lower & Vegetables & Innovative & Yes & No & Conv. \\
\hline F28 & $>60$ & 2 ha & Raiatea & Lower & Staple crops & Standard & Yes & Yes & Conv. \\
\hline F29 & $40-60$ & 0.1 ha & Raiatea & Higher & Vegetables & Innovative & No & Yes & Organic \\
\hline F30 & 40-60 & 2 ha & Raiatea & Lower & Mixed system & Innovative & No & Yes & Integrated \\
\hline F31 & $<40$ & 0.2 ha & Raiatea & Lower & Vegetables & Standard & Yes & No & Organic \\
\hline F32 & $>60$ & 2 ha & Raiatea & Lower & Mixed system & Standard & Yes & Yes & Integrated \\
\hline
\end{tabular}

years old. We evaluated 12 vegetable, nine mixed, five staple crops, four fruit, and two pineapple cropping systems. Overall, the pest management scores were closer to agroecological management (ScorePest $=5.5)$ than were the soil management scores $($ ScoreSoil $=4.8$ ) $($ Table 4$)$. They range from 0.8 to 10 for Score Soil for individual farms, and 0 to 10 for ScorePest. ScorePest and ScoreSoil were significantly correlated $\left(R^{2}=0.475\right.$, $p<0.001)$.

\section{Description of the Six Soil Management Practices}

On-farm organic matter recycling $(\mathrm{MP} 1=5.5)$ is not systematically used, even though it could represent an important source of nutrients and allow to limit bare soil exposure. Thirty percent of the farmers apply soil amendments, especially chicken manure and lime (Calcimer). Chicken manure is easy to achieve from the local laying hen factories and lime is applied especially by vegetable producers to increase soil $\mathrm{pH}$, although the latter is expensive and not many farmers can afford it. Compost is not widely used as many farmers claim its application is too timeconsuming.

Crop fertilization (MP2 $=4.5)$ is mostly based on synthetic mineral fertilizers (NPK 12-12-17) that are applied in one single application during the crop cycle. Split fertilization is not widely applied. Organic fertilizers are applied by $28 \%$ of the sampled farmers, some of them producing their fertilizers on the base of algae (providing $\mathrm{N}$-input) and fish bones (providing $\mathrm{P}-\mathrm{K}$-input) (Service Public, 2018b). Given that the preparation of these selfproduced fertilizers requires time, some farmers prefer to buy organically certified fertilizers from the market such as Orgaliz $(\mathrm{N})$, Physalg (P), and Patentkali (K).

Cover crops $(\mathrm{MP} 3=3.3)$ are rarely implemented on the farms, as land surface seems to be too scarce to allow the farmer not to produce for months. Only one farmer implements successfully a legume cover crop, Arachis pintoi (pinto peanut), grown under a pomelo orchard. 
TABLE 4 | Grading of the 11 management practices (MP) for the 32 farms.

\begin{tabular}{|c|c|c|c|c|c|c|c|c|c|c|c|c|c|}
\hline \multirow[t]{2}{*}{ Farm } & \multicolumn{6}{|c|}{ Soil management practices (MP 1-6) } & \multicolumn{5}{|c|}{ Weed and pest management practices (MP 7-11) } & \multirow[t]{2}{*}{ ScoreSoil } & \multirow[t]{2}{*}{ ScorePest } \\
\hline & MP1 & MP2 & MP3 & MP4 & MP5 & MP6 & MP7 & MP8 & MP9 & MP10 & MP11 & & \\
\hline F1 & 5 & 10 & 10 & 10 & 10 & 5 & 10 & 5 & 10 & 10 & 10 & 8.3 & 9.0 \\
\hline F2 & 5 & 5 & 0 & 0 & 0 & 5 & 0 & 5 & 5 & 5 & 0 & 2.5 & 3.0 \\
\hline F3 & 5 & 0 & 0 & 5 & 5 & 0 & 5 & 0 & $X$ & 0 & 5 & 2.5 & 2.5 \\
\hline F4 & 10 & 10 & 0 & 10 & 10 & 5 & 10 & 10 & 5 & 5 & 10 & 7.5 & 8.0 \\
\hline F5 & 0 & 0 & 0 & 0 & 5 & 5 & 10 & 10 & 0 & 0 & 5 & 1.7 & 5.0 \\
\hline F6 & 5 & 0 & 0 & 0 & 5 & 0 & 0 & 5 & 5 & 0 & 0 & 1.7 & 2.0 \\
\hline F7 & 0 & 5 & 0 & 0 & 0 & 10 & 0 & 0 & $x$ & 0 & 0 & 2.5 & 0.0 \\
\hline F8 & 5 & 5 & 5 & 10 & 5 & 0 & 10 & 5 & 5 & 5 & 5 & 5.0 & 6.0 \\
\hline F9 & 10 & 5 & 5 & 10 & 10 & 5 & 10 & 5 & 10 & 5 & 10 & 7.5 & 8.0 \\
\hline F10 & 0 & 5 & 0 & 5 & 0 & 0 & 0 & 0 & $x$ & 0 & 5 & 1.7 & 1.3 \\
\hline F11 & 10 & 5 & 5 & 10 & 10 & 0 & 10 & 10 & 10 & 5 & 5 & 6.7 & 8.0 \\
\hline F12 & 10 & 10 & $x$ & $x$ & 10 & 5 & 0 & 10 & $x$ & 10 & 5 & 8.8 & 6.3 \\
\hline F13 & 10 & 10 & 0 & 5 & 10 & 5 & 10 & 10 & 5 & 5 & 10 & 6.7 & 8.0 \\
\hline F14 & 5 & 5 & $X$ & $X$ & 10 & 10 & 10 & 5 & $X$ & 5 & 5 & 7.5 & 6.3 \\
\hline F15 & 5 & 10 & 0 & 5 & 10 & 10 & 10 & 10 & $x$ & 5 & 10 & 6.7 & 8.8 \\
\hline F16 & 0 & 5 & 0 & 0 & 5 & 5 & 0 & 10 & $x$ & 5 & 10 & 2.5 & 6.3 \\
\hline F17 & 0 & 10 & 5 & 5 & 5 & 10 & 10 & 10 & $X$ & 5 & 5 & 5.8 & 7.5 \\
\hline F18 & 0 & 5 & $x$ & $x$ & 5 & 10 & 0 & 10 & $X$ & 5 & 5 & 5.0 & 5.0 \\
\hline F19 & 10 & 10 & 10 & 5 & 5 & 5 & 10 & 5 & 5 & 0 & 5 & 7.5 & 5.0 \\
\hline F20 & 0 & 0 & 5 & 5 & 5 & 5 & 10 & 10 & 5 & 10 & 0 & 3.3 & 7.0 \\
\hline F21 & 10 & 5 & 10 & 0 & 5 & 5 & 0 & 5 & $x$ & 0 & 5 & 5.8 & 2.5 \\
\hline F22 & 10 & 0 & 10 & 0 & 5 & 5 & 5 & 5 & 5 & 0 & 0 & 5.0 & 3.0 \\
\hline F23 & 10 & 5 & 10 & 0 & 0 & 5 & 0 & 10 & 10 & 10 & 5 & 5.0 & 7.0 \\
\hline F24 & 10 & 10 & 0 & 10 & 10 & 10 & 10 & 10 & 0 & 10 & 10 & 10.0 & 10.0 \\
\hline F25 & 5 & 0 & 0 & 0 & 0 & 5 & 5 & 5 & 5 & 0 & 0 & 1.7 & 3.0 \\
\hline F26 & 10 & 0 & 0 & 0 & 5 & 0 & 5 & 10 & 5 & 5 & 0 & 2.5 & 5.0 \\
\hline F27 & 0 & 0 & 5 & 0 & 0 & 5 & 0 & 10 & 5 & 5 & 0 & 1.7 & 4.0 \\
\hline F28 & 5 & 0 & $x$ & $x$ & $x$ & 10 & 0 & 5 & $x$ & 5 & 5 & 5.0 & 3.8 \\
\hline F29 & 10 & 10 & 0 & 10 & 5 & 5 & 10 & 5 & 0 & 10 & 10 & 6.7 & 7.0 \\
\hline F30 & 0 & 0 & 0 & 0 & 0 & 5 & 0 & 10 & 5 & 10 & 5 & 0.8 & 6.0 \\
\hline F31 & 0 & 0 & 0 & 0 & 5 & 5 & 10 & 5 & 5 & 0 & 0 & 1.7 & 4.0 \\
\hline F32 & 10 & 0 & 10 & 5 & $x$ & 5 & 5 & 10 & 10 & 10 & 10 & 6.0 & 9.0 \\
\hline Mean & 5.5 & 4.5 & 3.3 & 3.9 & 5.3 & 5.2 & 5.5 & 7.0 & 5.8 & 4.7 & 5.0 & 4.8 & 5.5 \\
\hline
\end{tabular}

$X$, Management Practices non-existent in this cropping system. The bold values are used to highlight the Mean grade and the Scores.

Mulching (MP4 = 3.9) achieved a low score, which highlights that nutrient cycling still seems to lack in a large majority of the sample. Those who use mulching are mainly organic farmers who reintegrate organic matter in their systems by mulching the seedbed with on-farm produced organic matter to maintain soil moisture (and simultaneously decrease risks of soil erosion from wind/water). In many vegetable cropping systems, crop residues are destroyed chemically by applying herbicide (mainly glyphosate), and once the plants have died, the farmers use a rotavator/rototiller to re-integrate the crop residues in the soil. A couple of farmers without access to machinery, use fire to destroy their crop after harvest or to destroy a "spontaneous fallow" and re-prepare the soil bed. Pineapple producers and monoculture taro producers from the sample do not use mulching practices.
Various management practices are implemented to mitigate soil erosion (MP5 $=5.3)$. They include integrating semi-natural landscape elements such as planting trees or hedgerows in the borders of fields (against wind erosion), farming on raised beds (decrease water erosion), cropping along keylines on steep slopes (decrease water erosion), and applying plastic covers (decrease wind erosion and conserve soil humidity). Twentythree percent of the farmers did not implement any anti-erosion measures, whereas $30 \%$ of them designed their farming system to reduce erosion.

Tillage (MP6 $=5.2)$ is mostly shallow $(<15 \mathrm{~cm})$. Half of the farmers till mechanically using heavy machineries such as soc or disc plows. Twenty-five percent of the farmers till with a rototiller on the soil surface and $25 \%$ till by hand (crowbar/shovel). Tilling practices were very heterogeneous in the sample. 
TABLE 5 | Mean scores obtained for the two explanatory factors on ScoreSoil and ScorePest.

\begin{tabular}{llll}
\hline & & ScoreSoil & ScorePest \\
\hline $\begin{array}{lll}\text { Cropping system } \\
\text { (p-value }=0.008)\end{array}$ & Fruit $(n=4)$ & $7.8 \pm 2.1$ & $6.9 \pm 2.2$ \\
& Mixed system $(n=9)$ & $4.2 \pm 2.5$ & $6.9 \pm 1.4$ \\
& Staple crops $(n=5)$ & $5.2 \pm 1.6$ & $4.5 \pm 3.6$ \\
& Vegetables $(n=12)$ & $4.5 \pm 2.6$ & $5.1 \pm 2.3$ \\
& Pineapple $(n=2)$ & $2.1 \pm 0.6$ & $1.9 \pm 0.8$ \\
\hline Production system & Organic $(n=7)$ & $6.8 \pm 2.1$ & $7.5 \pm 1.8$ \\
(p-value $=0.023)$ & Integrated $(n=10)$ & $4.4 \pm 2.7$ & $5.7 \pm 2.3$ \\
& Conventional $(n=15)$ & $3.6 \pm 2.0$ & $4.1 \pm 2.2$ \\
\hline
\end{tabular}

n, number of farms; \pm , standard deviation.

\section{Description of the Seven Weed and Pest Management Practices}

Weed management (MP7 $=5.5)$ is dominated by chemical management: $38 \%$ of farmers used herbicides systematically (conventional vegetable producers, pineapple producers, taro monocultures). Forty-seven percent of the farmers, mostly the organic producers and the more resource-poor traditional farmers, managed weed mechanically or by hand weeding, as they cannot afford to buy herbicides or do not want to use them (organic farmers). One vegetable farmer was using the "stale seedbed ${ }^{3 "}$ technique as a weed management practice, which has the advantage of saving costs (avoid applying glyphosate that is expensive) and time (only two mechanical superficial tillage with machinery). Conventional pineapple producers used significant quantities of herbicides (usually ametrine) to limit competitive weed growth.

Farm agrobiodiversity (MP8 $=7.0)$ is the MP that obtained the highest score: $50 \%$ of the farmers obtained a score of 10 . Indeed, the majority of the farms consist of polyculture systems integrating evergreen perennials (such as banana) and woody perennials (breadfruit Artocarpus altilis, coconut trees, or other fruit trees). Diversity of harvested crops, use of non-harvested species that support food crop production, and non-harvested species in the wider environment seem to be important in the farming sample.

On farms dominated by vegetable production, crop rotations $(\mathrm{MP9}=5.8)$ are more rarely implemented than in farms where vegetables are part of a mixed system. Ten percent of the farmers grow one single crop and $65 \%$ of the farmers had a crop rotation composed of minimum of four crops. Only $25 \%$ of them based their crop rotation on the ecological needs of the plants such as alternating in botanical families. For example, on a period of a year, an example of rotation for an organic farmer would be lettuce, Chinese cabbage, radish, turnip, followed by about 5 months of fallow. A typical conventional farmer from our sample would grow cabbage, lettuce, and onion, which have high market

\footnotetext{
${ }^{3}$ A stale seed bed technique is a technique for weed control by creating a seedbed some weeks before the cash crop seed are due to be sown. The early seedbed is designed to germinate the weed seeds, that have been disturbed and brought to the soil surface during cultivation, so that the young weeds can be eliminated before the cash crop grows.
}

demand. The production cycles are generally very short, with no "fallow period" to restore soil fertility.

Cultivar choice $(\mathrm{MP} 10=4.7)$ differs a lot depending on the production system (organic, conventional, and integrated). Some farmers reuse plant genetic material by preparing cuttings, collecting seeds, or replanting plant shoots (especially the case for staple crops, fruits, and pineapple), which requires time. For vegetable producers, it is difficult to reuse plant genetic material and therefore new material is bought. Some of the organic vegetable farmers, try to use local landraces that are better adapted to the local climate and require fewer treatments such as winged bean Psophocarpus tetragonolobus. Some of the conventional and integrated vegetable farmers choose hybrid seeds that tend to be expensive but produce high yields and are resistant to fungal diseases and viruses.

Various biological pest control methods are used $($ MP11 $=$ 5.0 ) in the sample. Methods based on the introduction of natural enemies/pheromones is not widely used by farmers, with only a couple examples observed mostly on the organic farms. Among practices observed were sowing flower beds, spatially isolating crops from the same family such as Cucurbitaceae (decreasing the risks of contamination of fungal diseases between zucchini, cucumber, and squash), planting natural insect repellent plants such as lemongrass or French marigold (to protect against whiteflies), conserving grass strips to play the role of trap crop, hanging pheromone traps to attract fruit flies (especially for papaya tree) or applying biopesticides (limocide, Bacillus Thuringiensis, Neem oil, "bouillie bordelaise," baking soda, and black soap). Intercropping was not often observed inside the farmer sample. Sometimes, multiple crops are sown together, but mostly for practical reasons (optimization of land use) and not for ecological benefits. For the conventional vegetable producers, pest management is dominated by the application of pesticides, whereas in the mixed production system or fruit orchards, there is no application of any pesticide treatment, neither synthetic nor natural.

\section{Factors Explaining the Proximity to Agroecological Principles}

The Monte-Carlo permutation test showed that two factors, "cropping system" and "production system," significantly explain the farmers' ScorePest and ScoreSoil and hence their proximity to agroecological principles. Indeed, the cropping system $(p<$ 0.008 , with a significance level equal to $2.5 \%$ after a Bonferroni correction for two tests) significantly explains the farmers' proximity to agroecological principles. The production system (conventional, integrated, or organic) shows a significant but second-order effect on the scores $(p=0.023)$. These results could be expected and are not atypical. The other seven factors are likely to influence the farmers' management and hence the SoilScore and PestScore, but the statistical test was not able to highlight statistical significance.

When looking through a "cropping system" lens, Figure 1 shows a more scattered repartition of scores, where the pineapple farmers have scored the lowest in both the soil and pest management. Mixed systems stand out for their rather stable 


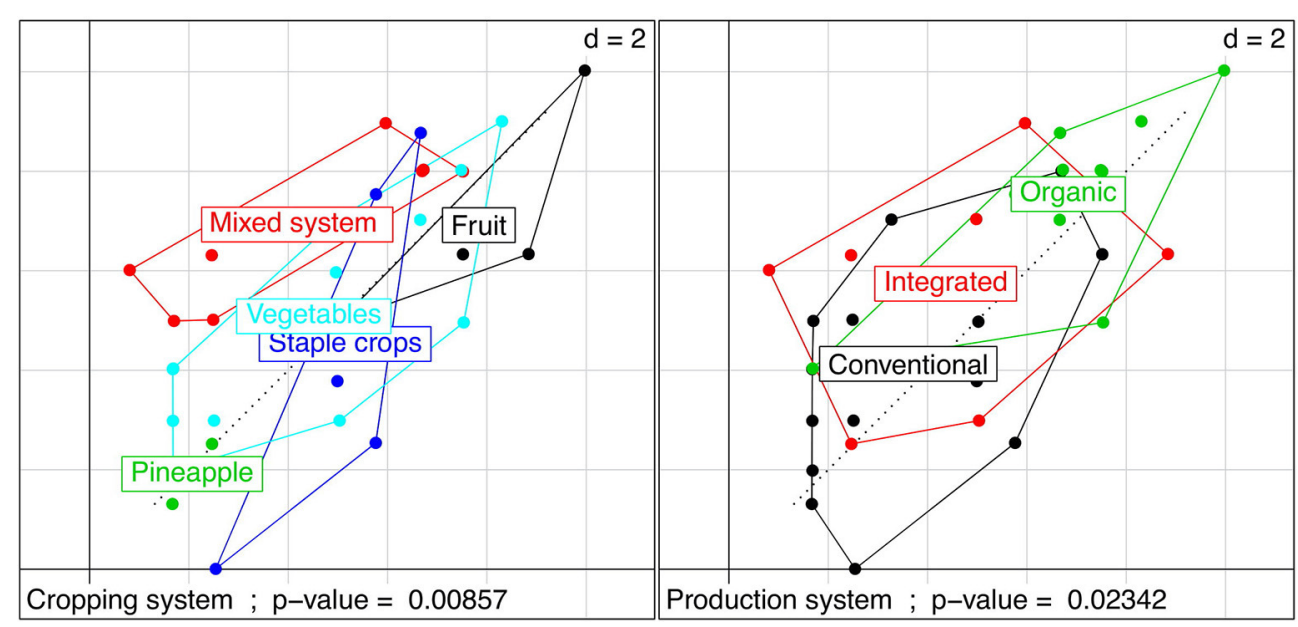

FIGURE 1 | The "cropping system" and "production system" significantly explain the farmers' ScorePest (y value) and ScoreSoil (x value) situated between 0 and 10 points.

high PestScore (lower and bigger variability for their SoilScore). Vegetable system scores show high variability, but there is a correspondence between ScorePest and ScoreSoil as the $\mathrm{x}$ value is aligned to the y value. Fruit systems have the highest scores in terms of pest (7.8) and soil (6.9) management (Table 5). However, this is based on only four farms producing mainly fruits. Mixed cropping systems have high pest management scores (6.4) but lower soil management scores (4.2). For the five staple crop producers, it is the opposite, with quite homogeneous soil management (5.2), but an important variability in terms of pest management (4.5).

When looking through a "production system" lens, Figure 1 shows that the seven organic farms have the higher scores in terms of pest (7.5) and soil (6.8) management whereas the 15 conventional farms have the lowest scores (4.1 and 3.6 for pest and soil respectively). The 10 integrated farms achieved intermediate soil and pest scores.

\section{DISCUSSION}

\section{Soil Management the Major Challenge for French Polynesian Farmers}

The farmers from our sample implement different soil and pest management practices that are in line with agroecological principles by utilizing ecological processes and ecosystem services for food production (Wezel et al., 2014). However, we have to acknowledge that due to our sampling strategy there might be an over-representation of integrated (10/32) and organic farmers (7/32 farmers), which is likely to overrepresent agroecological practices as more of these farmers where using them compared to the conventional farmers in our sample.

When going back to the six principles defined by Altieri and Nicholls (1999) it appears that three of them are well-followed $(2,4$, and 5$)$ with important harvested and non-harvested plant diversity allowing to strengthen the biological pest regulation of the agroecosystem. There is more margin for improvement in terms of soil management, especially concerning crop fertilization (MP2), cover crops (MP3), and mulching (MP4) which refers more to the principles (1), (3), and (6).

The less successfully implemented soil management practices are crop fertilization (MP2), cover crops (MP3), and mulching (MP4). Concerning crop fertilization (MP2), synthetic fertilizers application dominates as they are convenient to apply and much cheaper than the organic certified ones. Some farmers prepare their fish and algae fertilizer. However, it is time-consuming to collect and prepare the mixtures without sufficient machinery, and they are more difficult to apply in comparison to solid fertilizers from the store. Indeed, the algae and fish fertilizers are in a liquid form and they need to be diluted in large amounts of water before application with watering cans (often no irrigation system is available locally).

Concerning perennial cover crops (MP3) such as arachis pintoi and mulching, they are mostly sown in French Polynesia to decrease weed competition. Many different explanations coexist to explain their low implementation on the field. First, it is technically difficult to manage a successful establishment of a cover crop. In the case of Arachis pintoi, it appears that the cover crop grows slower than the more competitive surrounding weeds (Kartika et al., 2007). The cost of these legume seeds is also a barrier to further implementation as the success rate is still too low to convince farmers from investing financially in seeds [Wünscher et al., 2004, cited in Kartika et al. (2007)]. Some farmers implemented "spontaneous fallows" during their crop rotations, however, the rapid growth of grasses appearing require frequent mowing, which is challenging for farmers who do not possess machinery (rotavator, brush cutter), and this is the case for a majority of farmers in the sample. Second, knowledge and expertise for a successful implementation of cover crops and mulch are still lacking (INTEGRE, 2017). Another factor is the local culture with belief that "soil must remain clean" to 
avoid infestations from various non desired animals such as rats (Sautereau, 1994). And finally, there is also a cultural perception that sowing a cover crop represents a "loss of time" and therefore a lost opportunity to carry out another fieldwork.

Nevertheless, we observed some interesting use of a grass called "vetiver" (Chrysopogon zizanioides). It is usually grown on field borders and cut from time to time to be applied as a mulch and decrease weed pressure, whilst simultaneously decreasing soil erosion from wind and water. In addition, "the deep roots of vetiver allow to grow it on steep slopes, increase water infiltration and provide the desired grip action to reduce the chances of soil layer slippage in the occurrence of intense rainfall" (Gnansounou et al., 2017). These aspects are well-known by farmers that sow vetiver on the farming plot borders to achieve these specific benefits.

Mulching (MP4), cover crops, and fertility management are similarly not widely adopted by farmers in other similar tropical agroecosystems. Prosdocimi et al. (2016) state that even though organic mulching enhances soil fertility and decreases water runoff, its use in (sub)tropical developing countries amongst smallholders is low. They show that economic viability and feasibility regarding mulching application does not enhance broader adoption, as it depends on numerous factors such as biophysical, technological and institutional ones. Concerning cover crops, Daryanto et al. (2018) carried out a quantitative synthesis on ecosystem services of cover crops. They highlight that the practice can provide many ecosystem services. However, the limit to using cover crops is their complex management. The main limits mentioned are lack of knowledge and skills, access to cover crop seeds, training, and technical assistance. And finally, the ultimate factor that influences a farmer to adopt a new practiceaside from the production cost - remains the crop yield (Daryanto et al., 2018). The results from this study highlight similar results to those of Daryanto et al. (2018).

Gallagher et al. (1999) show that short-term improved fallows can be an important component of integrated weed management. Indeed, cover crops and green manures can serve as a trap-crop, catch-crop, or rotational crops, which has the advantage of managing parasitic weeds and simultaneously improving soil fertility. However, controlling weeds requires a commitment of substantial resources such as capital, labor, or pesticides, and is highly complex. For example, alternative weed management practices could be based on a combination of such practices: crop rotations, adapted soil tillage (to manage the depth of the seed bank), stale seedbed and adapted sowing dates, adapted sowing densities and row widths, competitive cultivars, and mechanical weeding. Meanwhile, these alternative practices are not likely to be implemented by farmers if they are not perceived as economically profitable (Chikowo et al., 2009).

Concerning fertility management, studied success factors for integrated soil fertility management in tropical agroecosystems leading to the adoption of alternative practices. The main factor influencing farmers' decisions to adopt them, is whether the economic benefits outweigh the costs. The authors show that it is important to have a joint approach with research actors, development institutions, and extension services in providing technical support and training for practices to be adopted to a larger extent.

\section{Factors Production Systems and Cropping Systems Most Influence Pest and Soil Management}

The factors production system and cropping system are explaining best farmers' PestScore and SoilScore, what we expected. Indeed, organic and agroecology share many similar principles (Migliorini and Wezel, 2017). Therefore, the organic farmers scored the highest in terms of proximity to agroecological principles.

When looking from a "production system" lens, Figure 1 shows clearly that organic production obtained the best scoresindependently from the cropping system-in comparison to integrated and conventional production. Conventional production systems obtained the lowest scores for all the different cropping systems. However, there are examples of interesting practices used by conventional farmers. For example, they were in majority the ones to apply lime as a soil amendment to basify the $\mathrm{pH}$ and they often had better knowledge of their soils (practiced regular soil analysis) which allows them to adapt the type of crop grown to the soil characteristics.

When looking at the scores from a "cropping system" lens, there is overall a good correlation between pest and soil management scores. Fruit cropping systems have the highest scores in terms of soil and pest management as they implement many biological pest management practices. It appears that it is easier to apply alternative practices to manage pests in fruit cropping systems than in vegetable cropping systems (e.g., black soap, neem oil, and choice of cultivars resistant to sooty mold). In addition, farmers explain that pressure from fungal diseases and viruses is lower for fruit trees (especially citrus orchards in our sample) in comparison to pest predation which is a problem in vegetable systems. Meanwhile, as our research is based on semi-directed interviews, we rely on farmers' declaration of practices. To understand better the effect of these practices, some field measurements would be required (such as crop yields, soil $\mathrm{pH}$, the amount of organic matter being returned in the system, or the dose of herbicides applied). Indeed, most of the vegetables produced in French Polynesia do not originate from the region and are not adapted to the local pedoclimatic conditions. This increases their sensitivity to pests. Soil management in fruit orchards is easier than for vegetables, as these perennial systems do not require soil tillage. Grass mowing usually with brush cutters was dominant in the fruit production systems. Concerning fertilization, practices observed inside the sample were compost application in the planting hole and around the tree base and application of wood pellets or coconut husks around the tree to maintain humidity and capture more water. Some fruit production systems such as intensive papaya monoculture used high amounts of herbicides between the trees, instead of mechanical management, which explains some of the lower scores inside this cropping system.

Inside the vegetable cropping systems, ScorePest and ScoreSoil were very heterogeneous (Figure 1) with the higher 
scores coming from the organic farmers and the lowest scores coming from the conventional ones. Some of the good practices observed in the organic vegetable systems are the use of flower beds sown next to the cash crops to attract beneficial insects that feed on crop predators, or the use of landraces such as the winged bean Psophocarpus tetragonolobus that grow without any fertilizer, fixes nitrogen in the soil and has a high tolerance to pests (personal communication by farmer A, 2018). In the conventional production systems, one innovative practice observed was the use of the stale seedbed practice to manage weed growth before sowing the cash crop and avoid applying herbicide. However, machinery is required to use this practice, and therefore, it was only observed once (personal communication by farmer B, 2018). Some of the conventional vegetable farmers also chose high-yielding cultivars that were resistant to fungal diseases, and to viruses. However, these cultivars are often expensive which draws them back from being widely used (personal communication by farmer C, 2018).

Staple crops systems scores achieved quite similar scores in terms of soil management, but the variability of the scores for pest management is important among farms (Figure 1 and Table 5). This can be understood by the fact that staple crops are mainly perennial crops that do not require frequent soil tillage activities (low soil disturbance), explaining higher soil management scores. Farmers producing staple crops are often the more "traditional ones" that live in Moorea or Raiatea and that do not produce for the competitive commercial vegetable markets. Their production logic is rather to achieve self-consumption and to sell the extra production as street vendors. Farming is often not the single activity of the farmers (fishing, handicraft), and therefore, there is less investment in the farming system (e.g., no machinery). Without access to some machinery, it is much more difficult to manage the weeds, and the farmers are therefore condemned to manage them by hand or with herbicides. One innovative staple production system observed was producing taro in combination with papaya trees. The papaya trees were planted on raised beds and the taro was intercropped in the lower hollows. This allowed optimizing land use, maintaining drained soil for the papaya and providing a humid and shady pit for the taro (personal communication by farmer D, 2018). More generally, the staple crop farmers growing various varieties of banana, plantain, sweet potato, cassava, and tarua did not need any pesticide management as they were avoiding monoculture plantations and were rotating the crops on their fields. Further research could focus on some of these intercropping systems to provide quantitative data on the potential synergies and validate these farmers' declarations.

Pineapple cropping systems obtained the lowest scores in terms of soil and pest management. They face weed management issues with three major weeds that tend to invade the pineapple crop (Joy, 2016). These weeds are managed with herbicide applications. There are still many technical challenges for integrated management of these weeds that would require a large palette of practices such as prophylactic, cultural, mechanical, and biological (use of bioagents and bio-pesticides) practices to avoid serious crop losses in pineapple (Joy, 2016). A current program is testing various cover crops, as it could be a way of avoiding non-desirable weed growth, and to simultaneously protect the soil from erosion (Service Public, 2018c). However, farmers are still not convinced by these alternative practices as the risk of failure remains too high (competition for nutrients and difficulties to manage cover-crops development in inter-rows). Indeed, pineapple production is usually located in steep slopes which make mechanical interventions difficult, and mowing the cover-crops in the inter-rows is not usual in farms and remains difficult due to the inter-rows space (personal communication by farmer E, 2018). In addition, the pineapple cropping system also leads to soil erosion as when the pineapple yields start to decrease (approximately after 6 years), the culture is often destroyed with heavy machinery which scraps the topsoil and the plant residues are burnt (personal communication by farmer E, 2018). This practice reinforces soil erosion naturally present on steep slopes and is for this reason destructive for the agroecosystem (Service Public, 2018c).

Finally, the scores for the mixed cropping systems are homogenous and usually high in terms of pest management. This can be explained by the fact that there is an important agrobiodiversity on the farms that might support natural biological pest regulation and enable reduction of pesticide use. However, soil management scores differ more greatly inside the mixed cropping systems as it depends mainly on three factors: the way herbicides are used, if the farmer owns machinery, and if organic matter is recycled on the farm. Some of the innovative practices observed in this group are rather linked to the farmers' market distribution channels, which is similar to those of some organic farmers, selling vegetable boxes and/or adding value to their products by producing jam or fruit puree (and decrease post-harvest losses).

\section{Drivers for Adoption of Agroecological Practices in French Polynesia}

Currently, the use of organic-based fertilizers is limited by their price, the decreased convenience for application, and the lack of machinery that hinders the use of natural fertilizers (personal communication by multiple farmers in the sample). Therefore, pooling farm equipment could be a driver to improve fertilization and also weed management as glyphosate use was mostly used by farmers who do not possess machinery. The municipality of Taputapuatea on the island of Raiatea has started to propose compost to farmers that are produced out of the local organic waste. This model could be reproduced in other municipalities and the concept could be extended to the offer of fish and algae fertilizer. This could ensure access to good quality fertilizers and would allow farmers to save some time. Cover crops were not widely used because of their complexity of implementation, and as well the expensive cost of the seeds (personal communication by farmer F, 2018). Sowing flower beds to attract plant auxiliaries are also suffering from their expensive price and the fact that the practice is still unknown by most farmers (personal communication by a farmer advisor, 2018). Simultaneously, landraces are usually cheap but not widely used because of consumer demand for "modern" crops (personal communication by a farmer advisor, 2018). For the latter, it seems 
that extension services have the responsibility to promote and explain to farmers and consumers why they should grow and eat landraces.

When looking at the current developments in French Polynesia, it appears that the Chamber of Agriculture and the Direction of Agriculture are conscious of these barriers and are implementing numerous actions to overcome them. Since 2016, the INTEGRE (INitiatives des TErritoires pour la Gestion Régionale de l'Environnement) Program conducted by the Agricultural Chamber started to publish online "technical leaflets" for organic production. Online leaflets are available to produce organic tomato, pepper, lettuce, zucchini, cucumber, cabbage, carrot, eggplant, and pineapple (INTEGRE, 2017). In addition, there are other technical leaflets available for the use of green manure and cover crops, and the production of fish and algae fertilizer. Access to such information and knowledge exchange inside farmers' networks will be a major driver for the broader adoption of agroecological practices, that require more complex management (Petit et al., 2012). Existing farmer networks already exist in French Polynesia via the Participatory Guarantee Systems (PGS) Bio Fetia that allows farmers to obtain the local organic label called "Bio Pasifika." The PGS Bio Fetia offers a good alternative for farmers who want to achieve organic standards but do not have the financial capacity to pay for external accreditation systems. Furthermore, the advantage of this PGS system lies in its promotion of social learning and exchange among organic farmer groups. Currently, nine local farmer groups exist with five of them located in the Society Archipelago (Windward and Leeward Islands). ${ }^{4}$ Additionally, the INTEGRE program ${ }^{5}$ is currently choosing "innovative bestfarms" all around the archipelagos to start working hand in hand with the farmers to develop trials for alternative practices. These two examples of existing farmer networks should allow to scaleout good practices from farmer to farmer and to ensure that the ecological knowledge and experience of indigenous Polynesian farmers are shared.

Consumer education can also be seen as a further driver for changes in practices. Bricas et al. (2001) conducted a study on the marketing and consumption of horticultural and fruit food products in French Polynesia. They highlight the potential of marketing for certain products: organic products, local traditional crops, locally processed foods (uru crisps, dried bananas/mangos, taro wheat...). Therefore, consumer education could support the transition, in parallel to farmer training, with well-targeted campaigns on new and sustainable diets such as the campaign "eat local" launched to enhance the consumption of traditional staple crops (Fabresse, 2018).

To conclude, this study has interviewed 32 farmers with the goal of identifying barriers and drivers for the adoption of agroecological practices and proposed a theoretical framework to analyze the proximity of farmers' management to agroecological principles. Results show that the interviewed farmers do

\footnotetext{
${ }^{4}$ Further information about the SPG Bio Fetia can be found here: https://www. tahiti-infos.com/Poeti-Lo-parcours-reve-au-SPG-Bio-Fetia_a198984.html.

${ }^{5}$ The INTEGRE program is now further developed under the name of PROTEGE: https://protege.spc.int/en.
}

implement different soil and pest management practices that are in line with agroecological principles and that overall, they seem to be more challenged to improve soil management than pest management. Many sampled farms showed having high levels of plant diversity, implemented crop rotations and mechanical weed management. Finally, we propose that the agricultural department in French Polynesia should focus on implementing farmer to farmer knowledge exchange and supporting demonstrations on farms to scale-out some of the agroecological practices observed. Moreover, training the local extension services staff about agroecological practices would be a further important avenue, supported by sensitizing consumers on the benefits of local staple crops and sustainably produced products.

\section{DATA AVAILABILITY STATEMENT}

The datasets presented in this article are not readily available because the dataset is in the possession of French Polynesia and cannot be shared. Requests to access the datasets should be directed to Philippe Couraud, phc.dag@gmail.com.

\section{ETHICS STATEMENT}

Ethical review and approval was not required for the study on human participants in accordance with the local legislation and institutional requirements. The patients/participants provided their written informed consent to participate in this study. To ensure ethical clearance, we anonymized all the data collected and we organized a workshop after carrying out the study to ensure that the farmers from the study could gain insights on agroecological practices that had been observed.

\section{AUTHOR CONTRIBUTIONS}

All authors listed have made a substantial, direct and intellectual contribution to the work, and approved it for publication.

\section{FUNDING}

This research has been funded by the Direction of Agriculture, Papeete (French Polynesia).

\section{ACKNOWLEDGMENTS}

First, we want to thank the farmers that have been selected to participate in this study on a voluntary basis and have shared their knowledge with us. Second, we would like to thank all the team working at the Direction of Agriculture in Tahiti, that supported this research. Further credits to Hineiti Lou Chao, who provided many insights to understand the challenges of the French Polynesian complex systems. Finally, we highly acknowledge funding from the Direction of Agriculture of Tahiti for the field research. 


\section{REFERENCES}

Agegnehu, G., and Amede, T. (2017). Integrated soil fertility and plant nutrient management in tropical agro-ecosystems: a review. Pedosphere 27, 662-680. doi: $10.1016 /$ S1002-0160(17)60382-5

Altieri, M. A., and Nicholls, C. I. (1999). "Biodiversity, ecosystem function and insect pest management in agricultural systems," in Biodiversity in Agroecosystems, eds W. W. Collins and C. O. Qualset (Boca Raton, FL: CRC Press), 69-84.

Bellard, C., Thuiller, W., Leroy, B., Genovesi, P., Bakkenes, M., and Courchamp, F. (2013). Will climate change promote future invasions? Global Change Biol. 19, 3740-3748. doi: $10.1111 / \mathrm{gcb} .12344$

Bricas, N., Etienne, J., and Mou, Y. (2001). Etude sur la commercialisation et la consommation des produits vivriers horticoles et fruitiers en Polynésie Française: Résultats de l'enquête de consommation alimentaire réalisée en Polynésie française en 1995. Pape'ete: Ministère de l'agriculture, Service du Développement Rural et le Centre de coopération International en Recherche Agronomique pour le Développement (CIRAD).

Capillon, A., and Manichon, H. (1991). Guide d'étude de l'exploitation agricole. Ed. InaPG/APCA. Relance Agronomique. Paris: Institut National Agronomique (INA), $1-65$

Carrère, M. C. (2017). Pesticides: les légumes importés pointés du doigt. Available online at: https://www.tahiti-infos.com/Pesticides-Les-legumesimportes-pointes-du-doigt_al66441.html (accessed July 10, 2018).

Casagrande, M., Alletto, L., Naudin, C., Lenoir, A., Siah, A., and Celette, F. (2017). Enhancing planned and associated biodiversity in French farming systems. Agron. Sustain. Dev. 37:57. doi: 10.1007/s13593-0170463-5

Cesarano, G., Zotti, M., Antignani, V., Marra, R., Scala, F., and Bonanomi, G. (2017). Soil sickness and negative plant-soil feedback: a reappraisal of hypotheses. J. Plant Pathol. 99, 545-570.

Chikowo, R., Faloya, V., Petit, S., and Munier-Jolain, N. M. (2009). Integrated Weed Management systems allow reduced reliance on herbicides and long-term weed control. Agri. Ecosyst. Environ. 132, 237-242. doi: 10.1016/j.agee.2009.04.009

Communauté du Pacifique Sud (2017). Plan d'action pour la Polynésie Française. INTEGRE/Plan d'action du projet/août $2014>$ janvier 2018. Available online at: https://integre.spc.int/images/pdf/INTEGRE/telechargements/pland-action-polynesie-francaise.pdf (accessed December 6, 2019).

Couraud, P. (1985). Origines et transformation de l'agriculture en Polynésie française - Analyse économique du secteur agricole. Thèse de doctorat. Agro-économie. Paris: Institut National Agronomique Paris-Grignon.

Daryanto, S., Fu, B., Wang, L., Jacinthe, P.-A., and Zhao, W. (2018). Quantitative synthesis on the ecosystem services of cover crops. Earth Sci. Rev. 185, 357-373. doi: 10.1016/j.earscirev.2018.06.013

Dray, S., and Dufour, A. (2007). The ade4 Package: implementing the duality diagram for ecologists. J. Statist. Softw. 22, 1-20. doi: 10.18637/jss.v022.i04

Fabresse, M. (2018). Lancement de la campagne "Manger Local". Available online at : https://www.capl.pf/agriculture/lancement-de-la-campagne-manger-local (accessed July 19, 2018).

FAO (2018). Guiding the Transition to Sustainable Food and Agricultural Systems. Rome: FAO.

FAO (2019). TAPE Tool for Agroecology Performance Evaluation 2019 - Process of development and guidelines for application. Test version. Rome: FAO.

Ferry, L. (1988). Contribution à l'étude des régimes hydrologiques de l'île de Tahiti. (Thèse de doctorat). Université de Paris Sud, Orsay, France.

Francis, C., Lieblein, G., Gliessman, S., Breland, T. A., Creamer, N., Harwood, R., et al. (2003). Agroecology: the ecology of food systems. J. Sustain. Agri. 22, 99-118. doi: 10.1300/J064v22n03_10

Gallagher, R. S., Fernandez, E. C. M., and McCallie, E. L. (1999). Weed management through short-term improved fallows in tropical agroecosystems Agroforest. Syst. 47, 197-221.

Gliessman, S. R. (2015). Agroecology: the Ecology of Sustainable Food Systems. Boca Raton, FL: CRC Press, Taylor and Francis. doi: 10.1201/b17881

Gnansounou, E., Alves, C. M., and Raman, J. K. (2017). Multiple applications of vetiver grass-a review. Int. J. Environ. Sci. 2, 125-141.

HLPE (2019). Agroecological Approaches and Other Innovations for Sustainable Agriculture and Food Systems That Enhance Food Security and Nutrition.
Rome: Committee on World Food Security, High Level Panel of Experts on Food Security and Nutrition, FAO. Available online at: http://www.fao.org/3/ ca5602en/ca5602en.pdf (accessed June 23, 2021).

Hope, A. C. (1968). A simplified Monte Carlo significance test procedure. J. R. Stat. Soc. 30, 582-598.

Institut d'émission d'outre-mer (2017). Rapport annuel 2016. Directeur de la publication: Marie-Anne POUSSIN-DELMAS. Responsable de la rédaction: Claude PERIOU. Etablissement Public National. Siège Social 164, rue Rivoli 750001 Paris. ISSN 1635-2262. Available online at: http://www.ieom.fr/ieom/ publications/rapports-annuels/2016.html (accessed October 6, 2018).

INTEGRE (2017). Plan daction Polynésie Française. Août 2014-Janvier 2018. Communauté du Pacifique (CPS) Nouméa Nouvelle-Calédonie. Available online at: http://integre.spc.int/images/pdf/INTEGRE/telechargements/pland-action-polynesie-francaise.pdf (accessed December 6, 2019).

Joy, P. (2016). Research and Development Report 2015-16 of the Pineapple Research Station. Kerala Agricultural University.

Kartika, J. G., Reyes, M. R., and Susila, A. D. (2007). "Review of literature on perennial peanut (Arachis pintoi) as potential cover crop in the tropics," in Tillage Systems and Soil Ecology. Soil \& Tillage Research, ed E. J. Kladivko (Greensboro, NC: North Carolina A\&T State University), 61-76.

Kladivko, E. J. (2001). Tillage systems and soil ecology. Soil. Tillage. Res. 61, 61-76. doi: 10.1016/S0167-1987(01)00179-9

Kopittke, P. M., Menzies, N. W., Wang, P., McKenna, B. A., and Lombi, E. (2019). Soil and the intensification of agriculture for global food security. Environ. Int. 132:105078. doi: 10.1016/j.envint.2019.105078

LEGIFRANCE (2004). Loi organique $n^{\circ}$ 2004-192 du 27 février 2004 portant statut dautonomie de la Polynésie française (1). Available online at: https:// www.legifrance.gouv.fr/affichTexte.do?cidTexte=JORFTEXT000000435515\& categorieLien $=$ cid (accessed December 8, 2019).

Magrini, M. B., and Triboulet, P. (2012). Transition agroécologique, innovation et effets de verrouillage: le rôle de la structure organisationnelle des filières. Cahiers Agri. 21, 34-45. doi: 10.1684/agr.2012.0539

McIntyre, B. D., Herren, H. R., and Wakhungu, J. (2009). Global Report (International Assessment of Agricultural Knowledge, Science and Technology for Development).

Méndez, V. E., Bacon, C. M., Cohen, R., and Gliessman, S. R. (eds.). (2015). Agroecology: A Transdisciplinary, Participatory and Action-Oriented Approach. CRC Press.

Meynard, J. M. (2012). La reconception est en marche! Conclusion au Colloque «Vers des systèmes de culture innovants et performants: De la théorie à la pratique pour concevoir, piloter, évaluer, conseiller et former $\gg$. Innovations Agronomiques (20). Paris: Institut national de recherche pour l'agriculture, l'alimentation et l'environnement (INRAE), 143-153.

Migliorini, P., and Wezel, A. (2017). Converging and diverging principles and practices of organic agriculture regulations and agroecology. A review. Agron. Sustain. Dev. 37:63. doi: 10.1007/s13593-017-0472-4

Ministère de l'Economie Rurale (2011). Politique agricole pour la Polynésie Française 2011-2020. Pape'ete: Ministère de l'Agriculture, de l'Elevage et de la Forêt.

Mottet, A., Bicksler, A., Lucantoni, D., De Rosa, F., Scherf, B. D., Scopel, E., et al. (2020). Assessing transitions to sustainable agricultural and food systems: a tool for agroecology performance evaluation (TAPE). Front. Sustain. Food Syst. 2020:579154. doi: 10.3389/fsufs.2020.579154

Nicholls, C. I., Altieri, M. A., and Vazquez, L. (2017). "Agroecological principles for the conversion of farming systems," in Agroecological Practices for Sustainable Agriculture: Principles, Applications, and Making the Transition, ed A. Wezel (New Jersey: World Scientific), 1-18. doi: 10.1142/9781786343062_0001

Olson, R. K., and Francis, C. A. (1995). "A hierarchical framework for evaluating diversity in agroecosystems," in Exploring the Role of Diversity in Sustainable Agriculture, eds R. Olson, C. Francis and S. Kaffka (Madison, WI: American Society of Agronomy, Crop Science Society of America, Soil Science Society of America), 5-34. doi: 10.2134/1995.exploringroleofdiversity.c1

Padel, S. (2001). Conversion to organic farming: a typical example of the diffusion of an innovation? Sociol. Ruralis 41, 40-61. doi: 10.1111/14679523.00169

Petit, M. S., Reau, R., Dumas, M., Moraine, M., Omon, B., and Josse, S. (2012). Mise au point de systèmes de culture innovants par un réseau d'agriculteurs et production de ressources pour le conseil. Innov. Agron. 20, 79-100. 
Prosdocimi, M., Tarolli, P., and Cerdà, A. (2016). Mulching practices for reducing soil water erosion: a review. Earth Sci. Rev. 161, 191-203. doi: 10.1016/j.earscirev.2016.08.006

Roche, H., Salvat, B., and Ramade, F. (2011). Assessment of the pesticides pollution of coral reefs communities from French Polynesia. Rev. Écol. 66, 3-10.

Rogers, E. M. (2003). "Elements of diffusion”, in Diffusions of Innovations, Vol. 5, (New York, NY: Free Press), 1-34.

Salembier, C., Elverdin, J. H., and Meynard, J. M. (2016). Tracking on-farm innovations to unearth alternatives to the dominant soybeanbased system in the Argentinean Pampa. Agron. Sustain. Dev. 36:1. doi: 10.1007/s13593-015-0343-9

Salvat, B., Roche, H., Berny, P., and Ramade, F. (2012). Recherches sur la contamination par les pesticides d'organismes marins des réseaux trophiques récifaux de Polynésie Française. Paris: Société nationale de protection de la nature et d'acclimatation de France.

Sautereau, N. (1994). Diagnostic de la situation agraire d'une petite région agricole polynésienne. Typologie des systèmes de productions à Taputapuatea (Raiatea). [Mémoire pour l'obtention du Diplôme d'Ingénieur Agronome]. Paris: Institut National Agronomique Paris-Grignon.

Seguin, F. (2015). Créocéan. Etat de l'environnement en Polynésie française 2007/2014. Direction de l'environnement, Polynésie française, Tahiti. Pape'ete: Direction de l'Environnement (DIREN), 381

Service du Développement Rural (2012). Recensement Général de l'Agriculture en Polynésie Française. Pape'ete: Situation de l'agriculture polynésienne en 2012.

Service du Développement Rural (2016). Bulletin de statistiques agricoles. Pape'ete: L'image de l'agriculture polynésienne en 2015.

Service Public (2018a). DAG Direction de l'Agriculture: Mode Biologique. Available online at: https://www.service-public.pf/dag/filiere-vegetale-agriculturepolynesie-francaise/mode-biologique/ (accessed December 5, 2019).

Service Public (2018b). DAG Direction de l'Agriculture: Mode Biologique, fiche technique de fabrication d'engrais de poisson. Available online at: https://www. service-public.pf/dag/filiere-vegetale-agriculture-polynesie-francaise/modebiologique/ (accessed December 5, 2019).

Service Public (2018c). DAG Direction de l'Agriculture: Mode Biologique, fiche technique pour l'ananas. Available online at: https://www.service-public.pf/ dag/wp-content/uploads/sites/28/2018/03/FTC-Ananas-PF.pdf (accessed December 5, 2019).
Wezel, A., Casagrande, M., Celette, F., Vian, J. F., Ferrer, A., and Peigné, J. (2014). Agroecological practices for sustainable agriculture. A review. Agron. Sustain. Dev. 34, 1-20. doi: 10.1007/s13593-013-0 180-7

Wezel, A., Gemmill Herren, B., Bezner Kerr, R., Barrios, E., Rodrigues Gonçalves, A. L., and Sinclair, F. (2020). Agroecological principles and elements and their implications for transitioning to sustainable food systems. A review. Agron. Sustain. Dev. 40:40. doi: 10.1007/s13593-020-00 646-z

Wotling, G., Bouvier, C.h., Danloux, J., and Fritsch, J.-M. (2000). Regionalization of extreme precipitation distribution using the principal components of the topographical environment. J. Hydrol. 233, 86-101. doi: 10.1016/S0022-1694(00) 00232-8

Wünscher, T., Schultze-Kraft, R., Peters, M., and Rivas, L. (2004). Early adoption of the tropical forage legume Arachis pintoi in Huetar Norte, Costa Rica. Expl. Agric. 40, 257-268. doi: 10.1017/S00144797030 01583 Gallagher, R.

Conflict of Interest: The authors declare that the research was conducted in the absence of any commercial or financial relationships that could be construed as a potential conflict of interest.

Publisher's Note: All claims expressed in this article are solely those of the authors and do not necessarily represent those of their affiliated organizations, or those of the publisher, the editors and the reviewers. Any product that may be evaluated in this article, or claim that may be made by its manufacturer, is not guaranteed or endorsed by the publisher.

Copyright (C) 2021 Surchat, Wezel, Tolon, Breland, Couraud and Vian. This is an open-access article distributed under the terms of the Creative Commons Attribution License (CC BY). The use, distribution or reproduction in other forums is permitted, provided the original author(s) and the copyright owner(s) are credited and that the original publication in this journal is cited, in accordance with accepted academic practice. No use, distribution or reproduction is permitted which does not comply with these terms. 